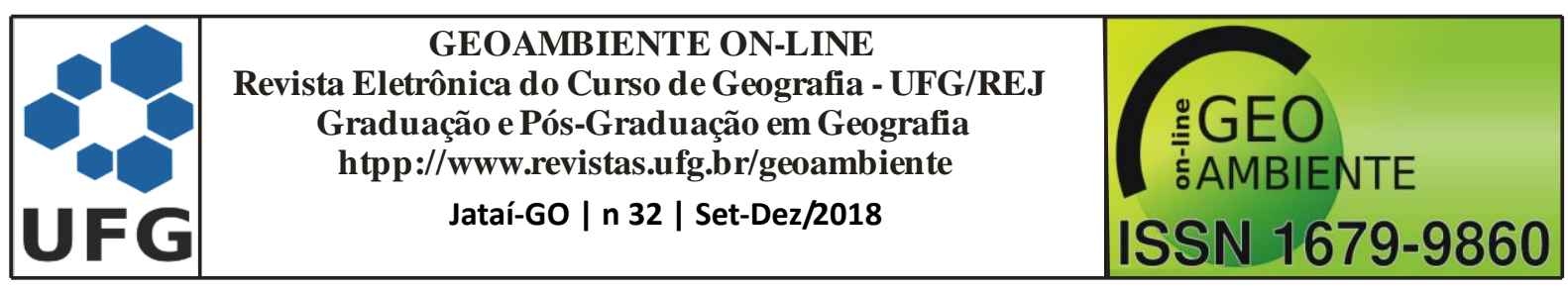

\title{
GÊNESE DA RACIONALIDADE AMBIENTAL UTÓPICA
}

\section{Munir Jorge Felício}

(Cátedra Unesco da Educação do Campo e Desenvolvimento Territorial, Pesquisador, Mestre em educação, Doutor em Geografia, email: munirjfelicio@gmail.com)

Resumo: O desafio deste texto consiste em incentivar o trabalho do pesquisador interdisciplinar ao contribuir na descoberta e/ou na criação de novas áreas e novos significados para ampliar sua compreensão sobre a questão ambiental. A racionalidade ambiental utópica dinamizará a sistematicidade e a complexidade por entender a questão ambiental como a desproporcionalidade do uso dos recursos naturais em atender as necessidades humanas básicas ou artificiais. Diante da escassez e do limite dos recursos naturais o desafio consiste em ampliar tais recursos e não esgotá-los como vem promovendo o avanço do sistema capitalista desde a Revolução Industrial. A racionalidade ambiental utópica não só é desejável como possível, desde que se compreendam os laços coercíveis da racionalidade econômica juntamente com as possibilidades de se lançar um novo itinerário cujo trajeto provoque rupturas com a ordem existente. Tentar elucidar este itinerário foi o objetivo principal deste texto.

Palavras-chave: racionalidade ambiental; utopia; coletivo de pensamento.

\section{GENESIS OF THE ENVIRONMENTAL RATIONALITY UTOPIAN}

Abstract: The challenge of this text is to encourage the work of the interdisciplinary researcher to contribute to the discovery and / or the creation of new areas and new meanings to broaden their understanding of environmental issues. The environmental rationality utopian catalyst in the systematic and the complexity of it by understanding the environmental issue as the disproportionality of the use of natural resources to meet basic or artificial human needs. Given the scarcity and the limits of natural resources, the challenge is to extend these resources and not exhausting them as promoting the advancement of the capitalist system since the Industrial Revolution. Environmental rationality Utopian is not only desirable but

\footnotetext{
Artigo recebido para publicação em 11 de Junho de 2018

Artigo aprovado para publicação em 28 de Novembro de 2018
} 


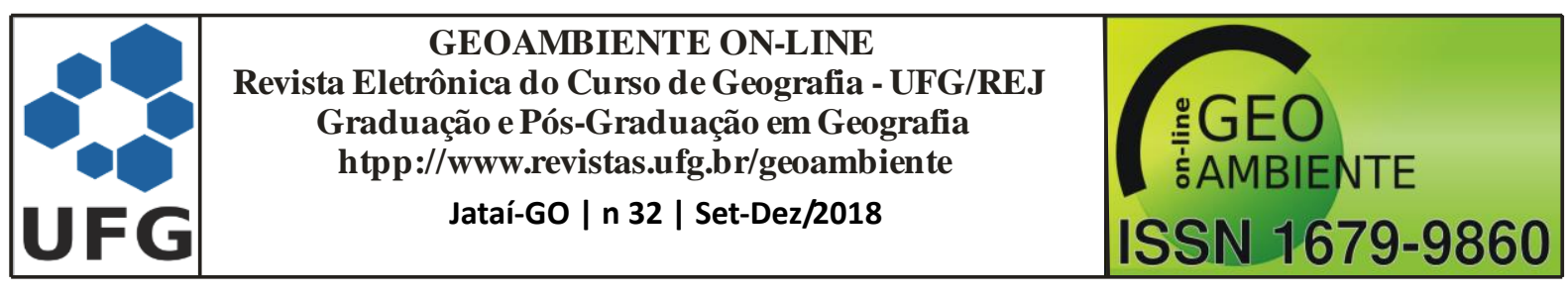

possible since it understands the contained ties of the economic rationality with the possibilities of launching a new route whose path causes disruptions to the existing order. Trying to elucidate this route was the main objective of this text.

Keywords: environmental rationality; Utopia; collective thinking.

\section{GÉNESIS DE LA RACIONALIDAD AMBIENTAL UTÓPICA}

Resumen: El desafío de este texto consiste en incentivar el trabajo del investigador interdisciplinario al contribuir en el descubrimiento y / o en la creación de nuevas áreas y nuevos significados para ampliar su comprensión sobre la cuestión ambiental. La racionalidad ambiental utópica dinamizará la sistematicidad y la complejidad por entender la cuestión ambiental como la desproporcionalidad del uso de los recursos naturales para atender las necesidades humanas básicas o artificiales. Ante la escasez y el límite de los recursos naturales, el desafío consiste en ampliar tales recursos y no agotarlos, como viene promoviendo el avance del sistema capitalista desde la Revolución Industrial. La racionalidad ambiental utópica no sólo es deseable como posible, desde que se comprendan los lazos coercibles de la racionalidad económica junto con las posibilidades de lanzar un nuevo itinerario cuyo trayecto provoque rupturas con el orden existente. Intentar elucidar este itinerario fue el objetivo principal de este texto.

Palabras clave: racionalidad ambiental; utopía; colectivo de pensamiento.

\section{Introdução}

O fato de não se compreender ou explicar uma coisa não significa que ela não exista. Esse raciocínio pode muito bem ser aplicado à racionalidade ambiental utópica, razão pela qual o presente texto procurar estabelecer um itinerário dialogando com diversas áreas do saber. Como utopia é conceito polissêmico, ela será considerada, neste itinerário, como perspectiva transformadora da ordem existente. Seu dinamismo constitui-se de alternativas potenciais criveis e viáveis para provocar rupturas parciais ou totais na ordem existente visando sua transformação.

A racionalidade ambiental utópica dinamizará a sistematicidade e a complexidade próprias do trabalho do pesquisador interdisciplinar por contribuir na descoberta e/ou na criação de novas áreas e novos significados da questão ambiental atual. Entende-se por 


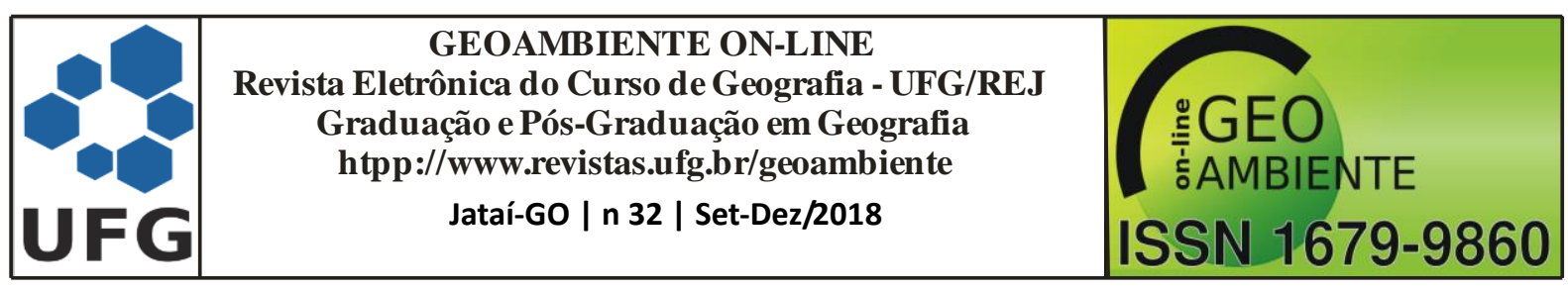

questão ambiental a desproporcionalidade do uso dos recursos naturais para atender as necessidades humanas, básicas ou artificiais. Diante da escassez e do limite dos recursos naturais, o desafio consiste em ampliar tais recursos e não esgotá-los como vem promovendo o avanço do sistema capitalista desde a Revolução Industrial.

O esforço deste texto consiste em propor um itinerário dividido em três momentos por intermédio dos quais fazer emergir a possível gênese da racionalidade ambiental utópica. No primeiro momento, as análises de Husserl (1986) e Kosik (1985) propiciarão conhecer as nuances e os desdobramentos da possibilidade do conhecimento à dialética do concreto. No segundo, as contribuições de Fleck (2010) e Heisenberg (2011) explicitarão como se dá a vinculação do saber ao coletivo de pensamento em que a dependência social e histórica são imprescindíveis na construção da ciência e, por fim, no terceiro momento as contribuições advindas das análises de Mannheim (1972) discutirão as distinções entre a mentalidade ideológica e a utópica.

\section{Da possibilidade do conhecimento à dialética do concreto: Husserl e Kosik.}

Interessa à fenomenologia husserliana elucidar o alcance e o limite das possibilidades cognitivas a partir das interconexões entre conhecimento e objeto. Ou seja, tentar compreender como e quando ocorre a transição do ser cognoscitivo em ser cognitivo. A essência do conhecimento encontra-se nessa transição por se revelar, a partir dela, a diversidade, complexidade, processualidade e pluridimensionalidade do saber humano, dada a sua capacidade de abstração. Compreender as alterações em meio às inúmeras possibilidades cognitivas é tarefa da fenomenologia, principalmente por ter, como ponto de partida, a certeza de que tais possibilidades são incontestáveis e indiscutíveis e, por conseguinte, não ser objetos de dúvida, como explica Husserl (1986, p. 22-23):

[...] se a teoria do conhecimento quiser concentrar-se na possibilidade do conhecimento, tem de ter conhecimentos sobre possibilidades cognitivas que, como tais, são indubitáveis e, claro está, conhecimentos no sentido mais estrito, a que cabe a apreensibilidade, e acerca da "sua" própria possibilidade cognitiva, cuja apreensibilidade é absolutamente indubitável.

As possibilidades cognitivas se desenvolvem por causa da ânsia do ser humano em compreender a realidade cujo primeiro contato se dá a partir do fenômeno e, distinguir nele, a aparência da essência. Emerge nesta distinção uma atração advinda da apreensibilidade 


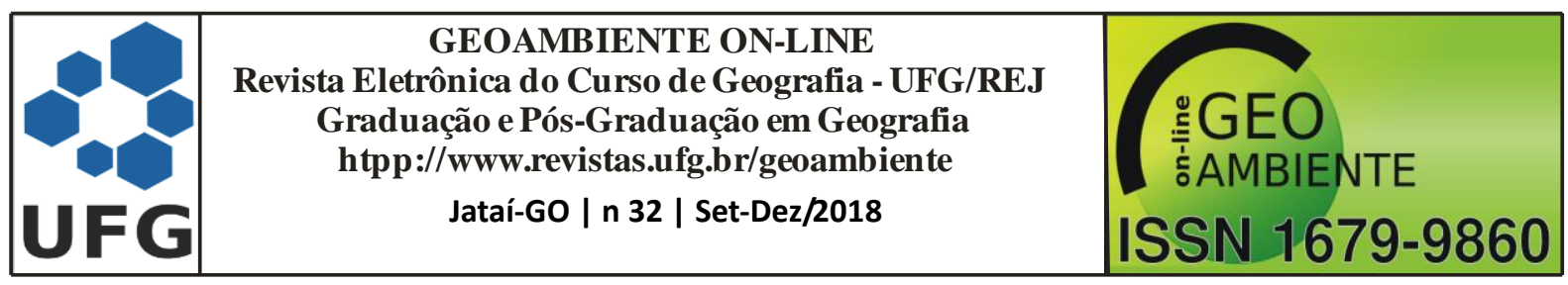

própria do conhecer humano visando obter esclarecimento e elucidação, como explica Husserl (1986, p. 25. Grifos no original):

O que eu quero é claridade, quero compreender a possibilidade deste apreender, isto é, se examino o seu sentido, quero ter diante dos meus olhos a essência da possibilidade de tal apreender, quero transformá-lo intuitivamente em dado. [...] A critica do conhecimento é uma ciência que quer continuamente, só e para todas as espécies e formas de conhecimento, criar claridade.

A capacidade de apreender e de assimilar constitui-se na gênese do processo de conhecimento a partir das impressões sensoriais, pelo contato que o ser humano tem com o mundo através dos sentidos. Todo o processo do conhecimento humano se desencadeia pela inferência de conceitos e coisas a partir das impressões sensoriais. E desta interconexão emerge a claridade e o desenvolvimento da compreensão como tarefas árduas do conhecimento humano, como explica Husserl (1986, p. 33. Grifos no original):

Mostra-se, pois, por toda a parte, esta admirável correlação entre o fenômeno do
conhecimento e o objecto de conhecimento. Advertimos agora que a tarefa da
fenomenologia, ou antes, o campo de suas tarefas e investigações, não é uma coisa
tão trivial como se apenas houvesse que olhar, simplesmente abrir os olhos. Já nos
casos primeiros e mais simples, nas formas ínfimas do conhecimento, se propõem à
análise pura e à pura consideração de essências as maiores dificuldades; é fácil falar
em geral da correlação, mas muito difícil elucidar, o modo como se constitui no
conhecimento um objeto cognoscitivo. E a tarefa é, agora, dentro do âmbito da
evidência pura ou do dar-se em si mesmo (Selbstgegebenheit), rastrear todas as
formas do dar-se e todas as correlações e exercer sobre todas elas a análise
esclarecedora.

Para Husserl (1986), a mola propulsora do processo de conhecimento consiste na investigação da constituição no conhecimento do objeto cognoscitivo, e, por conseguinte, compreender o "conhecimento do sujeito que conhece" como elucida Husserl (1986, p. 42), pois, ao

[...] falar de investigação dos objectos cognoscitivos e dos modos de conhecimento, se pensa sempre neste como investigação de essências, o qual, na esfera do que se dá de maneira absoluta, salienta genericamente o sentido último, a possibilidade, a essência da objectalidade do conhecimento e do conhecimento da objectalidade (HUSSERL, 1986, p.35).

A questão central da investigação de essências é formulada nos seguintes termos: "como pode o conhecimento estar certo da sua consonância com os objetos conhecidos, como pode ir além de si e atingir fidedignamente os objectos?" (HUSSERL, 1986, p. 42). Ou seja, 


\begin{tabular}{|c|c|c|}
\hline & $\begin{array}{c}\text { GEOAMBIENTE ON-LINE } \\
\text { Revista Eletrônica do Curso de Geografia - UFG/REJ } \\
\text { Graduação e Pós-Graduação em Geografia } \\
\text { htpp://www.revistas.ufg.br/geoambiente } \\
\text { Jataí-Go | n } 32 \text { | Set-Dez/2018 }\end{array}$ & $\begin{array}{c}\text { :GEO } \\
\text { G. AMBIENTE } \\
\text { G }\end{array}$ \\
\hline
\end{tabular}

"como pode o fenômeno puro do conhecimento atingir algo que lhe não é imanente, como pode o conhecimento (absolutamente dado em si mesmo) atingir algo que não se dá em si absolutamente? E como pode compreender-se este atingir? (HUSSERL, 1986, p. 27).

Trata-se do esforço humano para conhecer-se conhecendo o mundo e, nesse diálogo dinâmico e processual, organizar-se, organizando o mundo, pois, "o conhecimento é, apenas conhecimento humano, ligado às formas intelectuais humanas, incapaz de atingir a natureza das próprias coisas, as coisas em si” (HUSSERL, 1986, p. 44. Grifos no original).

Ao distinguir ciência natural de ciência filosófica, Husserl (1986, p. 41) esclarece que as possibilidades cognitivas naturais não causam preocupações para a crítica do conhecimento por serem alternativas impulsionadas pela percepção (pré-gnoseológica). As possibilidades cognitivas filosóficas acionadas pela intelecção (gnoseológica) estabelecem "dificuldades abissais", por engendrar a "reflexão sobre a relação entre conhecimento e objeto". Para ele (p.43) "só os fenômenos são verdadeiramente dados ao cognoscente" e a "reflexão gnoseológica origina a separação de ciência natural e filosofia" (p. 46). Husserl (1986) almeja atingir a essência do conhecimento e desenvolve sua fenomenologia em parte como ciência, em parte como método e em parte como filosofia. Para Husserl (1986, p. 46. Grifos no original) a

'Fenomenologia' - designa uma ciência, uma conexão de disciplinas científicas; mas, ao mesmo tempo e acima de tudo, 'fenomenologia' designa um método e uma atitude intelectual: a atitude intelectual especificamente filosófica, o método especificamente filosófico.

Como método especificamente filosófico, a fenomenologia propicia compreender as inúmeras possibilidades cognitivas de que dispõe o ser humano e, como ser cognoscitivo, só o ser humano se desenvolve com inata vivência intelectiva. Diante de tais características se manifesta Husserl (1986, p. 58. Grifos no original):

Ora, o que eu queria dizer é que o correcto em tudo isto é que, no início, não pode valer nenhum conhecimento como previamente dado sem exame. Mas, se à crítica do conhecimento não é lícito aceitar de antemão nenhum conhecimento, pode então começar por a si mesma dar conhecimento e, naturalmente, conhecimento que ela não fundamenta, não infere logicamente - o que exigiria conhecimentos imediatos, que deveriam previamente ser dados -, mas conhecimento que ela imediatamente mostra e que é de uma espécie tal que exclui, com clareza e de modo indubitável, toda a dúvida sobre a sua possibilidade, e nada absolutamente contém do enigma que fornecera a ocasião de todas as perplexidades cépticas. 


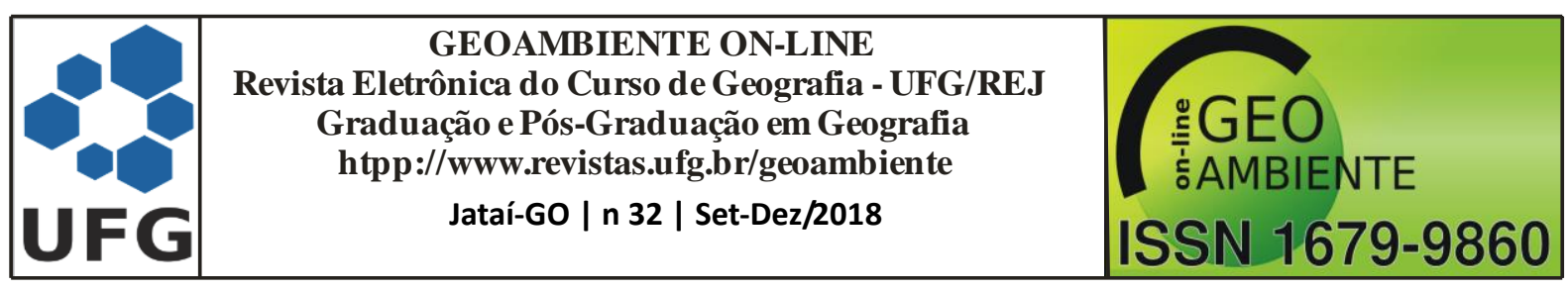

Pelas possibilidades cognoscitivas, a vivência intelectiva tende ir além de si mesma e perceber ou intuir além do percebido, além do dado, além do que empiricamente capta no e do fenômeno, ou, onde ele se deixa ver ou se pode ver, pois, "a palavra 'fenômeno' tem dois sentidos em virtude da correlação essencial entre o aparecer e o que aparece" (HUSSERL, 1986, p. 35. Grifos no original). A possibilidade cognoscitiva é "uma possibilidade sabida, mas não dada em si mesma, não intuída", uma vez que o conhecimento não se confunde com o objeto do conhecimento, pois, "o conhecimento é uma coisa distinta do objecto do conhecimento; o conhecimento está dado, mas o objecto cognoscitivo não está dado; e, no entanto, o conhecimento deve referir-se ao objecto, tem de o conhecer" (HUSSERL, 1986, p.63).

Almeja a fenomenologia de (Husserl, 1986) ampliar a compreensão da interconexão e do desenvolvimento das implicações entre o conhecimento e o objeto. A questão central para ela emerge a partir da questão: o que, de fato, acontece entre esses dois pólos? Ao tentar encontrar a essência do conhecimento, a fenomenologia analisa o processo de transição das vivências cognoscitivas para as cognitivas. O que significa conhecer a transformação do ser cognoscitivo em ser cognitivo quando ele experimentar, no seu processo mental desencadeado pelo seu contato com o fenômeno, o conhecer-se conhecendo o mundo. A partir de então começa a organizar-se organizando o mundo.

Somam-se às análises de Husserl (1986) as contribuições de Kosik (1985), por propiciarem a compreensão dos desdobramentos advindos das atividades que o ser cognoscitivo executa, necessariamente, diante do mundo que se descortina em sua frente por intermédio das manifestações fenomênicas. Trajeto este único a proporcionar abertura por intermédio da qual atingir a essência da realidade, pois, nela estão unidos de forma indissociável o fenômeno e a essência, como explica Kosik (1985, p. 12. Grifos no original):

O fenômeno não é radicalmente diferente da essência, e a essência não é uma realidade pertencente a uma ordem diversa da do fenômeno. Se assim fosse efetivamente, o fenômeno não se ligaria à essência através de uma relação intima, não poderia manifestá-la e ao mesmo tempo escondê-la; a sua relação seria reciprocamente externa e indiferente. Captar o fenômeno de determinada coisa significa indagar e descrever como a coisa em si se manifesta naquele fenômeno, e como ao mesmo tempo nele se esconde. Compreender o fenômeno é atingir a essência. Sem o fenômeno, sem a sua manifestação e revelação, a essência seria inatingível. 


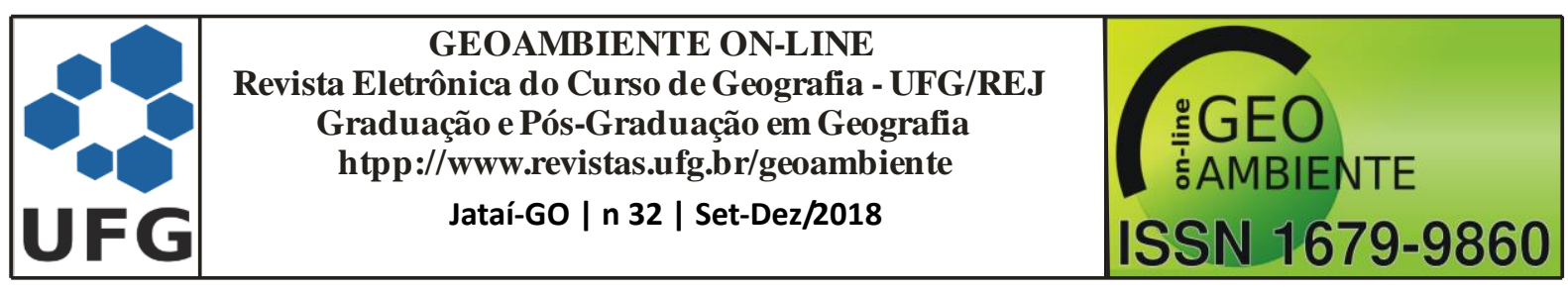

A transição do ser cognoscitivo em ser cognitivo por intermédio das possibilidades cognoscitivas, como explicou Husserl (1986), consiste na peculiar e insubstituível atividade humana em examinar a realidade a partir da aparência fenomênica até conseguir captar a sua essência fundamental, pois, "se a aparência fenomênica e a essência das coisas coincidissem diretamente, a ciência e a filosofia seriam inúteis" (Kosik, 1985, p. 13).

Ao entrar em contato com a realidade, o ser congnoscitivo dispõe de todas as potencialidades para se apropriar dela, encontrando ou descobrindo, ou ainda criando uma via própria de acesso à ela, pois, ele "sempre vê mais do que aquilo que percebe imediatamente" (KOSIK, 1985, p. 22. Grifos no original). Por conseguinte, ao criar essa via própria de acesso, percebe a realidade como totalidade complexa e indivisível, diante da qual vai conhecendo a realidade por criar para si a realidade humana na qual almeja interferir.

O enriquecimento do saber humano se amplia na medida em que o sujeito cognitivo consegue distinguir no fenômeno o seu aspecto aparente e identificar a essência, pois, a realidade consiste numa totalidade complexa e dinâmica, a qual não se dissipa inteiramente na sua mera imagem física. Aqui se encontra o ponto nodal de importância fundamental para o trabalho do pesquisador interdisciplinar com a necessária construção e o desenvolvimento da racionalidade ambiental, principalmente ao intensificar a vigilância epistemológica para não permitir que a abundância dos fenômenos particulares provoque nele ilusão.

As considerações de Kosik (1985, p. 25-26. Grifos no original) são imprescindíveis para esta trajetória:

\footnotetext{
Cada objeto percebido, observado ou elaborado pelo homem é parte de um todo, e precisamente este todo não percebido explicitamente é a luz que ilumina e revela o objeto singular, observado em sua singularidade e no seu significado. A consciência humana deve ser, pois, considerada tanto no seu aspecto teórico-predicativo, na forma do conhecimento explícito, justificado, racional e teórico, como também no seu aspecto antepredicativo, totalmente intuitivo. A consciência é constituída da unidade de duas formas que se interpenetram e influenciam reciprocamente, porque, na sua unidade, elas se baseiam na práxis objetiva e na apropriação prático-espiritual do mundo.
}

Como a realidade não se apresenta ao ser humano de forma imediata, mas é ele que, abstratamente, constrói representações com as quais pretende conhecer e interferir nela e empreende-se na necessária transição do abstrato ao concreto. $\mathrm{Na}$ construção destas representações encontram-se as possibilidades cognoscitivas, por intermédio das quais, o ser cognoscitivo se transforma em cognitivo, pois, 


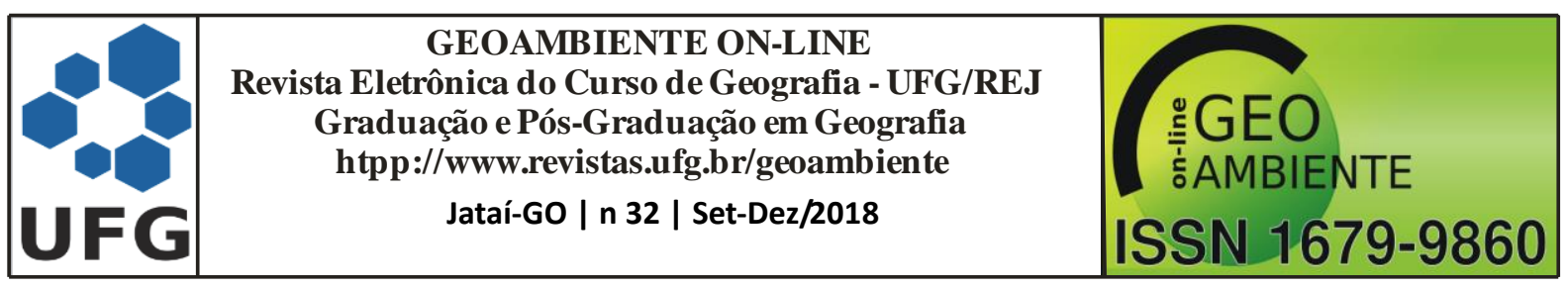

[...] o todo não é imediatamente cognoscível para o homem, [...] o todo é imediatamente acessível ao homem, mas é um todo caótico e obscuro. [...] o concreto se torna compreensível através da mediação do abstrato, o todo através da mediação da parte. [...] Para que o pensamento possa progredir do abstrato ao concreto, tem de mover-se no seu próprio elemento, isto é, no plano abstrato que é a negação da imediaticidade, da evidência e da concreticidade sensível. A ascensão do abstrato ao concreto é um movimento para o qual todo início é abstrato e cuja dialética consiste na superação desta abstratividade. O progresso da abstratividade à concreticidade é, por conseguinte, em geral movimento da parte para o todo e do todo para a parte; do fenômeno para a essência e da essência para o fenômeno; da totalidade para a contradição e da contradição para a totalidade; do objeto para o sujeito e do sujeito para o objeto (KOSIK, 1985, p. 30. Grifos no original).

Ao tratar da construção da racionalidade ambiental, a concepção de totalidade kosikiana contribui por lançar luzes à compreensão das problemáticas ambientais atuais como uma totalidade imediatamente acessível, porém, caótica e obscura, por ser resultado de inúmeros processos e de dimensões diversas. Trata-se de super exploração dos recursos naturais, acrescida da "degradação socioambiental, a perda da diversidade biológica e cultural, a pobreza associada à destruição do patrimônio dos povos, [...] a distribuição desigual dos custos ecológicos do crescimento e a deterioração da qualidade de vida" como explicou Leff (2007, p. 159-160).

Diante deste todo caótico e obscuro, a racionalidade ambiental poderá emergir por intermédio da escolha de "uma demanda externa" (LEFF 2007, p.142) e, a partir dela, negar sua imediaticidade, evidência e concrecidade, para poder superar o espontaneismo e restabelecer, no pensamento, a autentica realidade em si, com suas contradições possibilidades. A escolha da demanda externa é importante por ter potencial para violar "as expectativas paradigmáticas que governam a ciência normal” (KHUN, 2009, p. 78) e transformar a questão ambiental em questão sistêmica. Como questão sistêmica, as problemáticas ambientais como todo imediatamente acessível ao pesquisador interdisciplinar é compreendido na sua complexidade, integralidade, unicidade e indivisibilidade na qual se sobrepõe as dimensões químicas, sociais, humanas, políticas, ideológicas, culturais, econômicas, cientificas, utópicas, biológicas, industriais, entre tantas outras.

A intencionalidade da racionalidade ambiental almeja ampliar a compreensão dos processos evolutivos referente às problemáticas ambientais, investigando suas inúmeras interconexões como uma totalidade sistêmica e dialética. Por isso é indispensável transformar a categoria da totalidade em princípio epistemológico e em exigência metodológica do conhecimento da realidade, como esclarece Kosik (1985, p. 35-36. Grifos no original): 


\begin{tabular}{|c|c|c|}
\hline & $\begin{array}{c}\text { GEOAMBIENTE ON-LINE } \\
\text { Revista Eletrônica do Curso de Geografia - UFG/REJ } \\
\text { Graduação e Pós-Graduação em Geografia } \\
\text { htpp://www.revistas.ufg.br/geoambiente } \\
\text { Jataí-Go | n } 32 \text { | Set-Dez/2018 }\end{array}$ & $\begin{array}{c}\text { :GEO } \\
\text { G. AMBIENTE } \\
\text { G }\end{array}$ \\
\hline
\end{tabular}

Totalidade significa: realidade como um todo estruturado, dialético, no qual ou do qual um fato qualquer (classes de fatos, conjuntos de fatos) pode vir a ser racionalmente compreendido. Acumular todos os fatos não significa ainda conhecer a realidade; e todos os fatos (reunidos em seu conjunto) não constituem, ainda, a totalidade. Os fatos são conhecimento da realidade se são compreendidos como fatos de um todo dialético - isto é, se não são átomos imutáveis, indivisíveis e indemonstráveis, de cuja reunião a realidade saia constituída - se são entendidos como partes estruturais do todo. O concreto, a totalidade, não são, por conseguinte, todos os fatos, o conjunto dos fatos, o agrupamento de todos os aspectos, coisas e relações, visto que a tal agrupamento falta ainda o essencial: a totalidade e a concreticidade. Sem a compreensão de que a realidade $e ́$ totalidade concreta - que se transforma em estrutura significativa para cada fato ou conjuntos de fatos - o conhecimento da realidade concreta não passa de mística, ou a coisa incognoscível em si.

A compreensão das problemáticas ambientais como totalidade sistêmica exige a concepção dialética do todo estruturado, diante do qual o estudo das partes e dos processos isolados, contribui apenas para a concepção restrita da realidade na sua dimensão física. Ao tratar das problemáticas ambientais, o pesquisador interdisciplinar incluir-se-á também nas suas análises, pois, de tais análises ele é parte integrante tanto do problema, quanto da solução. Para Kosik (1985, p. 40. Grifos no original) a

[...] investigação dialética da realidade social é o ponto de vista da totalidade concreta, que antes de tudo significa que cada fenômeno pode ser compreendido como momento do todo. Um fenômeno social é um fato histórico na medida em que é examinado como momento de um determinado todo; desempenha, portanto, uma função dupla, a única capaz de dele fazer efetivamente um fato histórico: de um lado, definir a si mesmo, e de outro, definir o todo; ser ao mesmo tempo produtor e produto; ser revelador e ao mesmo tempo determinado; ser revelador e ao mesmo tempo decifrar a si mesmo; conquistar o próprio significado autentico e ao mesmo tempo conferir um sentido a algo mais.

O pesquisador interdisciplinar das Ciências Ambientais é continuamente desafiado a desenvolver sua pesquisa a partir da demanda externa, tratando-a como momento do todo. A demanda externa emerge como fenômeno e, como ponto de partida, quando o investigador interdisciplinar estabelece contato tendo consciência que se trata, por enquanto, de um todo caótico e obscuro. Pelas possibilidades cognitivas é importante que o pesquisador, de início, negue a imediaticidade, a evidência e a concreticidade quando da transição do ser cognoscitivo em ser cognitivo, demonstrando a importância da interdependência entre o fenômeno do conhecimento e o objeto do conhecimento, como explicou anteriormente Husserl (1986). 


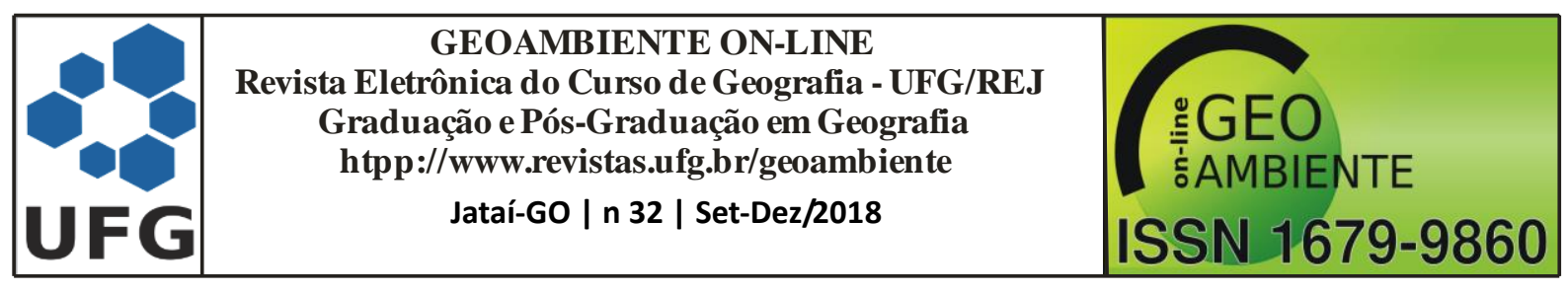

A demanda externa como fenômeno revela e esconde, simultaneamente, a essência proporcionando ao pesquisador interdisciplinar criar uma via própria de acesso, pela possibilidade de ver mais do que consegue perceber imediatamente. A importância desse ineditismo consiste na possibilidade do pesquisador se deparar com impasses, dilemas e crises, como ocasiões propícias, para promover a ruptura e/ou superação das expectativas paradigmáticas próprias das ciências normais, como quer Kuhn (2009). Principalmente por evidenciar que tais impasses e crises não se constituem eventos isolados, mas de importância vital, por não ser possível compreender as problemáticas ambientais atuais utilizando os mesmos paradigmas que as engendraram. Eis como emerge a dimensão utópica da racionalidade ambiental a partir da demanda externa e do trabalho do pesquisador interdisciplinar. Trabalho esse que de forma alguma se constitui na individualidade, mas num longo processo coletivo pela necessidade de novos olhares, como explica Fleck (2010).

\section{A vinculação do saber ao coletivo de pensamento: dependência social e histórica. Fleck e}

\section{Heisenberg}

As análises de Fleck (2010, p. 70) ampliam a compreensão da importância da interdisciplinaridade em duas direções: por evidenciar que o trabalho interdisciplinar é necessário, mas não suficiente, pois, “cada época tem concepções dominantes, restos das concepções passadas e predisposições de concepções futuras, em analogia com todas as formas sociais" e, por compreender que a dimensão utópica da racionalidade ambiental, como tarefa do pesquisador interdisciplinar, ainda se encontra na protoideia ou pré-ideia a ser desenvolvida na medida em que são impulsionadas as "mutações do estilo de pensamento" (FLECK, 2010, p. 67-68).

A protoideia direciona a construção e o desenvolvimento do conhecimento por intermédio de seu potencial, riqueza e diversidade como explica Fleck (2010, p. 67), pois, “o valor dessa pré-ideia não reside em seu conteúdo lógico e 'objetivo', mas unicamente em seu significado heurístico enquanto potencial a ser desenvolvido". A força da protoideia dinamiza e orienta o intenso tráfego de pensamentos em uma comunidade científica, engendrando, paulatinamente, a subordinação mental.

No desenvolvimento estrutural do edifício de conhecimentos a protoideia circulará de indivíduo a indivíduo formando um pensamento coletivo cada vez mais dinâmico até se 


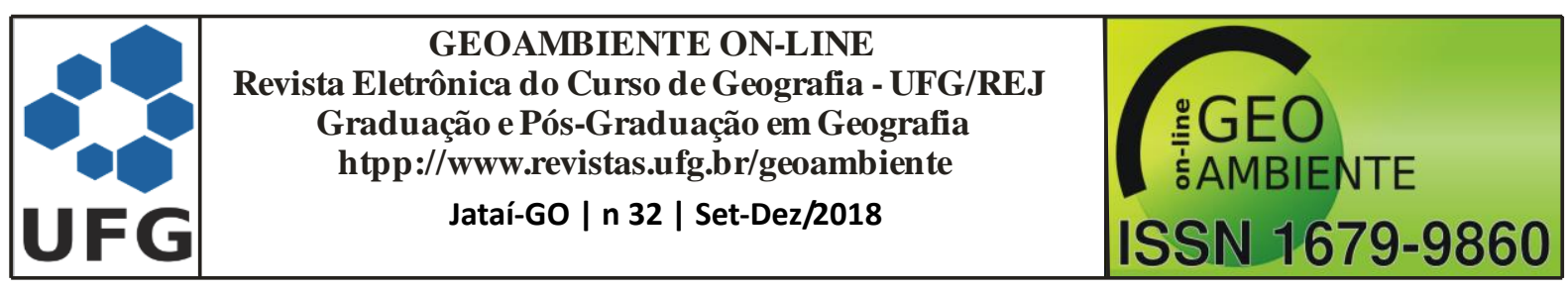

constituir na idéia transpessoal cujo dinamismo adquire força coercitiva para dar solidez ao coletivo de pensamento. A transição da protoideia em idéia transpessoal é imprescindível para engendrar a "dependência intelectual recíproca entre os indivíduos e uma atmosfera (Stimmung) comum", como quer Fleck (2010, p. 158). Este condicionamento social demonstra, por conseguinte, que "o processo de conhecimento não é o processo individual de uma 'consciência em si' teórica; é o resultado de uma atividade social, uma vez que o respectivo estado do saber ultrapassa os limites dados a um indivíduo" (FLECK, 2010, p. 81$82)$.

A estrutura harmônica responsável por desenvolver o conhecimento engendrará um sistema de opinião fechado com estilo próprio de pensamento, pois, como explica Fleck (2010, p. 83-84) conhecer significa,

[...] em primeiro lugar, constatar os resultados inevitáveis sob determinadas condições dadas. Estas condições correspondem aos acoplamentos ativos, formando aquilo que é percebido como realidade objetiva. $\mathrm{O}$ ato da constatação compete ao indivíduo. Os três fatores que participam do processo de conhecimento, a saber, o indivíduo, o coletivo e a realidade objetiva (aquilo que é para ser conhecido), não são seres metafísicos: também são passíveis de análise, isto é, há ainda outras relações entre eles. Essas outras relações derivam do fato de, por um lado, o coletivo ser composto por indivíduos e, por outro, de a realidade objetiva poder ser dissolvida nos contextos das idéias históricas e coletivas. [...]. Apesar de consistir em indivíduos, o coletivo de pensamento não é a simples soma deles. O indivíduo nunca, ou quase nunca, está consciente do estilo de pensamento coletivo que, quase sempre, exerce uma força coercitiva em seu pensamento e contra o qual qualquer contradição é simplesmente impensável.

O trabalho científico, como tarefa coletiva, consiste na atividade humana vinculada e dependente das condições sociais, fazendo circular a ideia transpessoal por intermédio da linguagem. A transição da ideia transpessoal se efetiva como atividade coletiva, avança como produto social e é dependente da interpretação e da intencionalidade em razão do uso da linguagem. É a linguagem o meio pelo qual se desenvolve a protoidéia em idéia transpessoal, por gerar dependência recíproca entre receptor e emissor. $\mathrm{O}$ receptor entenderá o pensamento do emissor a partir de sua própria interpretação e intencionalidade. Por conseguinte, um determinado pensamento peregrinando no interior da comunidade científica é transformado constantemente, pois, “após uma série dessas peregrinações, não sobra praticamente nada do conteúdo original. De quem é o pensamento que continua circulando? Nada mais é do que um 


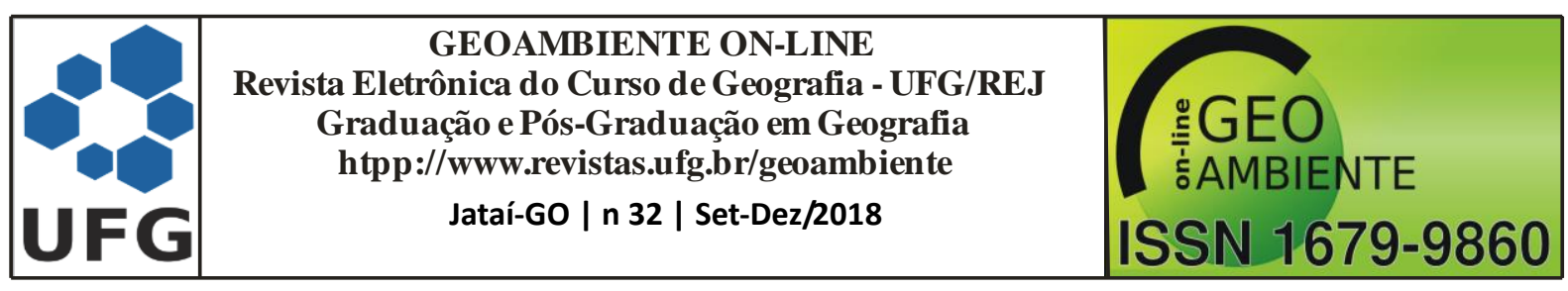

pensamento coletivo, um pensamento que não pertence a nenhum indivíduo" como entende Fleck (2010, p. 85).

À medida que os conhecimentos são transmitidos e começam a circular na comunidade científica, sofrem transformações, são fortalecidos e aperfeiçoados. Eles exercem influências e interferem em outros conhecimentos, como também nos hábitos de pensar. Para Fleck (2010, p. 86) "todo o acervo de conhecimento e a interação mental coletiva influenciam cada ato de conhecimento que, sem eles, seria, em princípio, impossível”. Essa coerção coletiva de pensamento é tão necessária, pois,

[...] aquilo que pensa no homem não é ele, mas sua comunidade social. A origem do seu pensamento não está nele, mas no meio social onde vive, na atmosfera social na qual respira, e ele não tem como pensar de outra maneira a não ser daquela que resulta necessariamente das influências do meio social que se concentram no seu cérebro (FLECK, 2010, p. 90. Grifos no original).

A imprescindibilidade do estilo de pensamento é condição para a geração do pensamento impulsionando seu desenvolvimento e superação como mola propulsora para a construção do edifício de conhecimentos. Fleck (2010, p. 110) entende que

O estilo de pensamento não é apenas esse ou aquele matiz dos conceitos e essa ou aquela maneira de combiná-los. Ele é uma coerção definida de pensamento e mais: a totalidade das disposições mentais, a disposição para uma e não para outra maneira de perceber e agir. [...] Uma vinculação do saber ao coletivo de pensamento, uma coerção social exercida no pensamento.

A vinculação do saber ao coletivo de pensamento engendra um campo gravitacional de importância vital a dirigir o estilo de pensamento no curso das ideias em que as diferenças de opinião vão sendo superadas na medida em que é exercida, no pensamento, a coerção cognitiva, uma vez que "quanto mais elaborada uma área de conhecimento, quanto mais desenvolvida, tanto menores as diferenças de opinião" (FLECK, 2010, p. 132). Quanto mais o pesquisador se aprofunda numa área do saber tanto maior se torna seu vínculo a um estilo de pensamento. "Quanto mais se entra numa área cientifica, tanto maior se torna o vínculo com o coletivo de pensamento e tanto maior a ligação imediata com o pesquisador" (FLECK, 2010, p. 131).

Por ser o pensamento uma atividade social por excelência, o processo de conhecimento se desenvolve numa comunidade, uma vez que "o saber vive no coletivo e é continuamente retrabalhado" como explica Fleck (2010, p. 145). A coercibilidade de 


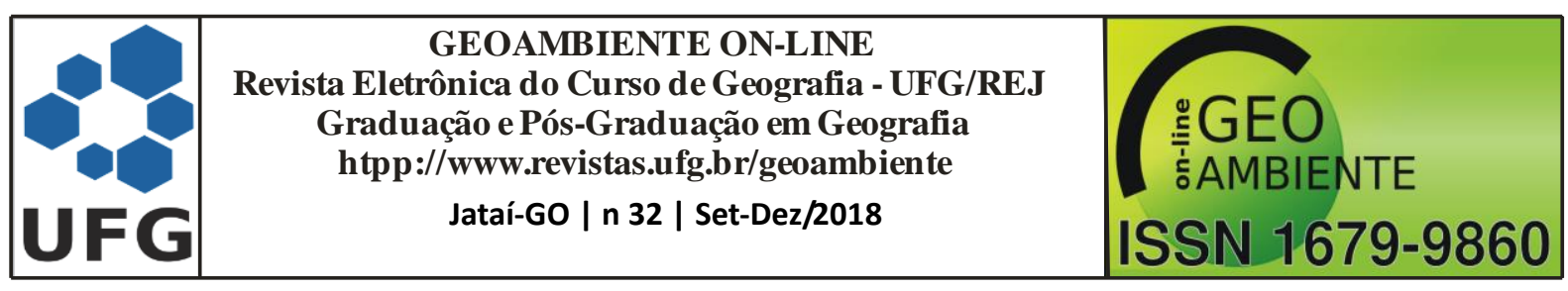

pensamento exercida pelo coletivo garante a consolidação do edifício de conhecimentos, e "a tendência geral do trabalho de conhecimento é, portanto, um máximo de coerção de pensamento (Denkzwang) com um mínimo de pensamento baseado na própria vontade" (FLECK, 2010, p. 144).

Para ressaltar essa coercibilidade de pensamento, Fleck (2010, p.149. Grifos no original) compara o processo do conhecimento à dinâmica de um jogo de futebol ou à harmonia em uma orquestra. Para ele

\begin{abstract}
Uma orquestra pode mesmo ser vista a partir do trabalho de instrumentos isolados, sem consideração pelo sentido e pelas regras de colaboração? O estilo de pensamento contém essas regras para o pensamento. Todos os caminhos de uma teoria fecunda do conhecimento desembocam no conceito de estilo de pensamento, cujas variantes podem ser comparadas e estudadas enquanto resultado de um desenvolvimento histórico. [...] Podemos, portanto, definir o estilo de pensamento como percepção direcionada em conjunção com o processamento correspondente no plano mental e objetivo. Esse estilo é marcado por características comuns dos problemas, que interessam a um coletivo de pensamento [...].
\end{abstract}

O coletivo de pensamento pode ser momentâneo ou casual, estável ou relativamente estável que se configura pelo fechamento como um mundo particular, contudo, não está adstrito a um grupo fixo ou a determinada classe social. Para Fleck (2010, p. 154) "sempre temos um coletivo de pensamento, quando duas ou mais pessoas trocam idéias: são coletivos momentâneos ou casuais de pensamento, que aparecem e desaparecem a cada momento". O vocabulário peculiar, os interesses intelectuais, a coerção de pensar e o hábito de pensar formam um sistema harmonioso configurando as características dos coletivos de pensamento.

A vinculação ao estilo de pensamento condiciona as possibilidades de percepção e de aplicação. De percepção quando o novato inicia em um estilo de pensamento, ele descobre que "algo até então invisível se lhe torna visível” (FLECK, 2010, p. 155). De aplicação quando, diante de uma rachadura no revestimento, o "pintor vê apenas os danos de superfície e os trata como tais; o pedreiro pensa no conjunto da parede e tende, também na prática a intervir na profundidade da parte interna" (FLECK, 2010, p. 156). Por conseguinte, a cada estilo de pensamento corresponde um condicionamento social e dependência histórica, as quais estabelecem a vinculação do saber ao coletivo de pensamento.

Os meandros da gênese da física atômica, descrita por Heisenberg (2011), lança luzes esclarecedoras possibilitando ampliar a compreensão referente às contribuições de Fleck (2010), principalmente no que tange ao vínculo do saber com o coletivo de pensamento. É 


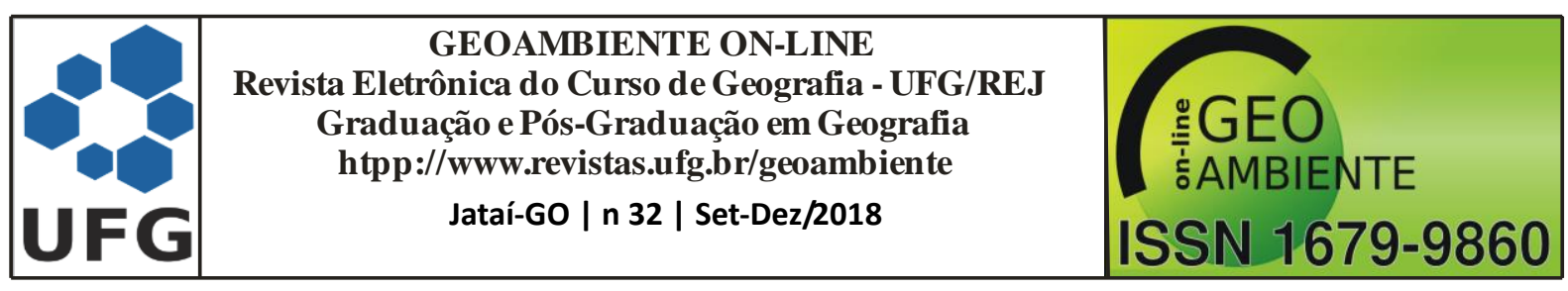

possível identificar a formação de tal coletivo apreciando os inúmeros diálogos e encontros travados entre cientistas como Heisenberg, Eisntein, Bohr, Planck, Dirac, dentre outros. Para expor o dinamismo do processo de criação da física atômica, Heisenberg (2011, p. 8. Grifos no original) resgatou conversas e trocas de idéias sobre física, filosofia, religião e política reproduzindo a

[...] atmosfera em que ocorreram as conversas, pois nela se torna claro o processo criativo da ciência. Ela ajuda a explicar como a cooperação entre pessoas pode culminar em resultados científicos da máxima importância. O autor pretendeu transmitir, inclusive aos que estão muito distantes da física atômica, uma impressão dos movimentos de pensamento [Denkbewegungen] que acompanharam a história do surgimento dessa ciência.

Os diálogos e debates sobre o mundo dos átomos, segundo Heisenberg (2011), foram imprescindíveis para romper com o casulo epistêmico em que cada pesquisador estava adstrito, como confirma Heisemberg (2011, p. 10): "não tínhamos medo de formar nossos próprios juízos sobre os mais difíceis problemas”. A troca de idéias num emaranhado de opiniões, próprio de um coletivo de pensamento, visa propiciar a circulação dos pensamentos nos quais se encontravam os conceitos. É o ser humano transformando coisas em ideias e organizando-as em forma de conceitos. Ocorre que os átomos não são acessíveis à observação direta e, por conseguinte, “provavelmente não são coisas" expôs Heisenberg (2011, p. 20).

Estas e outras dimensões compõem os principais questionamentos da novíssima teoria atômica a exigir dos cientistas o desenvolvimento da racionalidade utópica própria daqueles que se lançam numa terra virgem promissora a desbravar novas possibilidades de pensamento e de descobertas cientificas num vasto horizonte inexplorado. Foi o que ocorreu no encontro entre Werner Heisenberg e Niels Bohr no início da década de 1920 quando discutiam os dilemas advindos da compreensão sobre a estrutura dos átomos.

Neste início do coletivo de pensamento com a troca de ideias entre dois cientistas sobre a estrutura dos átomos, a ideia transpessoal, ia sendo impulsionada pela racionalidade utópica, sem a qual, a ciência não evolui. Quando Bohr (HEISENBERG, 2011, p.47) tentou descrever a estrutura do átomo "como um minúsculo sistema planetário, cuja massa estava quase toda concentrada em um núcleo central, consideravelmente menor do que o próprio átomo. Em torno desse núcleo giravam elétrons muito leves, equiparados aos planetas", estava utilizando muito mais a "intuição e inspiração" (p.51) do que a própria robustez do raciocínio lógico. 


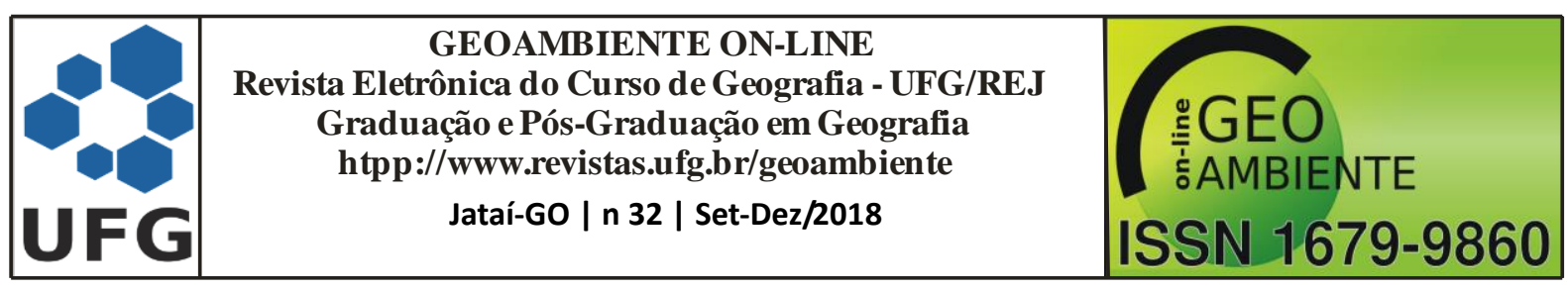

Constatou Bohr que, na física atômica, "todos os conceitos anteriores revelaram-se insuficientes. A estabilidade da matéria nos mostra que a física newtoniana não se aplica ao interior do átomo" (HEISENBERG, 2011, p.53). Os conceitos clássicos apenas contribuíram como orientação ocasional e, assim, já não eram mais aplicáveis na compreensão da estrutura dos átomos, certos de que, "os átomos não eram coisas" (p. 55). Descortinava-se diante de Heisenberg e Bohr o desafio em

[..] deixar o ancoradouro seguro da doutrina aceita e enfrentar o perigo de um arriscado salto à frente em direção ao vazio. [...] Entretanto, quando se trata de enveredar por novos territórios, a própria estrutura do pensamento cientifico (e não apenas o seu conteúdo) pode ter que se alterar, para que seja possível compreender o novo (HEISENBERG, 2011, p.87).

A abertura de novos campos do saber para compreender a estrutura do átomo alteraria o arcabouço científico que, até então, apesar de seguro, mostrava-se inadequado como constatou Bohr, "os processos envolvidos não são objetos da experiência direta. Não os percebemos diretamente, assim, nossos conceitos não são adaptáveis a esses processos" (p. 91). A gênese de todas as dificuldades estava na constatação de que os conceitos da física clássica se referiam a fatos, a objetos observáveis, enquanto os processos atômicos tratavam de possibilidades e aproximações.

$\mathrm{Na}$ tentativa de ampliarem a compreensão do que acontece no interior do átomo Heisenberg (2011, p. 96-98) propôs o "princípio da incerteza da mecânica quântica” e Bohr "o conceito de complementaridade", contudo, não conseguiram convencer Einstein, que tinha dificuldade em aceitar as possibilidades e as aproximações como características próprias da física atômica por dedicar "a vida a investigar o mundo objetivo de processos físicos que têm lugar no espaço e no tempo, independentes de nós, de acordo com leis exatas”.

As possibilidades, as aproximações e o acaso fazem parte da interpretação dos fenômenos atômicos identificados por Heisenberg (2011, p. 141) ao tentar entender os movimentos do elétron no interior do núcleo atômico ao afirmar que "é impossível dizer em que direção um elétron será emitido", pois,

Sempre que tentamos deduzir leis a partir de nossos estudos dos fenômenos atômicos, descobrimos que já não correlacionamos processos objetivos no espaço e no tempo, mas apenas situações observacionais. Somente para estas é que podemos deduzir leis empíricas. Os símbolos matemáticos com que descrevemos essas situações observacionais representam possibilidades, e não fatos (HEISENBERG, 2011, p.145). 


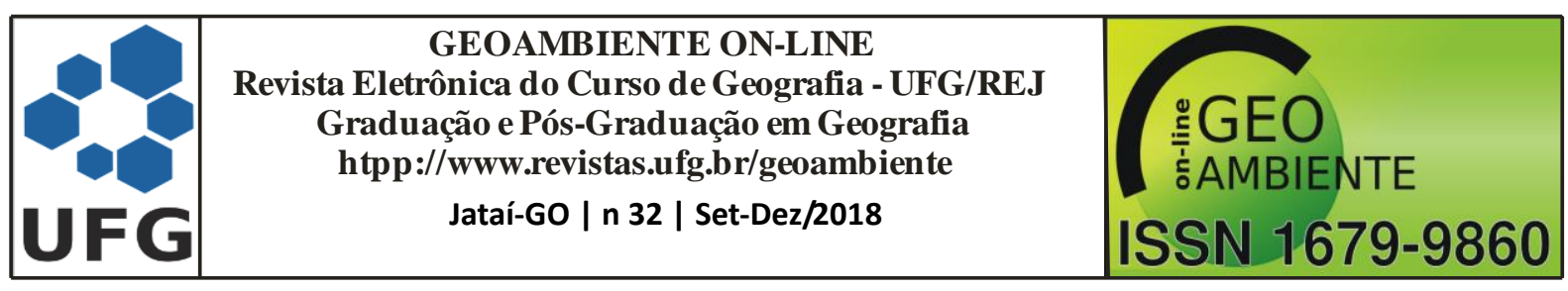

Entre os dilemas da física atômica encontrava-se a linguagem com a qual expressar os resultados advindos das situações observacionais, das quais, os átomos fazem parte, e "têm um alto valor explicativo na análise física dos fenômenos" (p.145). Os físicos atômicos não haviam ainda desenvolvido a linguagem própria e utilizavam a da física clássica até que os experimentos se desenvolvessem e outra linguagem fosse construída com o devido cuidado cientifico como afirmou Borh "a ciência é a observação de fenômenos e a comunicação dos resultados a terceiros, que têm que verificá-los. Só temos uma base para o entendimento depois de concordarmos sobre o que aconteceu objetivamente, ou sobre o que acontece com regularidade" (HEISENBERG, 2011, p.154).

Tal concordância faz parte do desenvolvimento do coletivo de pensamento pela intensa troca de idéias impulsionando, entre os cientistas, a circulação da ideia transpessoal até criar ou, se preciso engendrar, uma formação discursiva própria para a física atômica explicar os fenômenos descobertos e poder comunicar o inédito. Assim avança a ciência ao esculpir, desenvolver ou substituir os conteúdos de conceitos já existentes e, neste caso, ao seu tempo, não estarão mais adstritos aos conceitos da física clássica. Portanto, o uso da linguagem é imprescindível para a circulação, construindo uma coesão entre os cientistas, vinculando-os ao coletivo de pensamento por intermédio de um novo saber, como explicou Niels:

\footnotetext{
Um dos pressupostos básicos da ciência é falarmos das mensurações numa linguagem que tem essencialmente a mesma estrutura daquela com que falamos da experiência cotidiana. Aprendemos que essa linguagem é um meio de comunicação e orientação inadequado. Apesar disso, ela é o pressuposto de todas as ciências (HEISENBERG, 2011, p.154).
}

É a linguística estrutural a ciência responsável em demonstrar que a linguagem é uma instituição social, constituindo-se num processo criativo que serve ao pensamento para divulgar os dados apreendidos pelos sentidos, todavia, sua importância consiste em transportar a ideologia de um lugar a outro. Dentre os autores que tentaram compreender as interconexões entre pensamento, linguagem, ideologia e sociedade, se destaca Mannheim (1972, p. 29) por suas análises se dedicarem "ao problema de como os homens realmente pensam". O objetivo da obra dele consiste em investigar como o pensamento "realmente funciona na vida pública e na política como instrumento de ação coletiva”.

\section{A concepção de utopia em Mannheim}




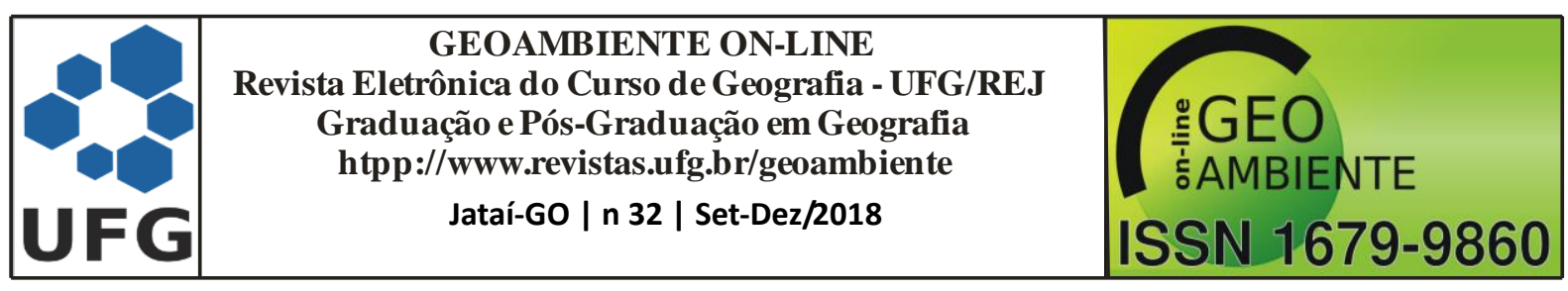

As análises mannheiminianas, em consonância com as fleckianas, já tratadas neste texto, ampliam e desdobram a compreensão de que a gênese do pensamento não se encontra exclusivamente no indivíduo. Não é a pessoa que pensa, a comunidade é que pensa nela. Para Fleck (2010, p. 84) “o indivíduo nunca, ou quase nunca, está consciente do estilo de pensamento coletivo que, quase sempre, exerce uma força coercitiva em seu pensamento e contra o qual qualquer contradição é simplesmente impensável”. Para Mannheim (1972, p. 31)

[...] quem pensa não são os homens em geral, nem tampouco indivíduos isolados, mas os homens em certos grupos que tenham desenvolvido um estilo de pensamento particular em uma interminável série de respostas a certas situações típicas características de sua posição comum.

Conhecer as nuances da gênese social de onde emana o estilo de pensamento abre horizontes para a compreensão da interferência e da coerção da racionalidade coletiva sobre a capacidade abstrativa individual. Nesta, a força coercitiva direciona para uma e não para outra maneira de pensar, vez que seria falso, como elucidou Mannheim (1972), "daí deduzir que todas as ideias e sentimentos que motivam o indivíduo tenham origem apenas nele, e que possam ser adequadamente explicados tomando-se unicamente por base sua experiência de vida".

É inegável que o estilo de pensamento da racionalidade econômica atualmente é hegemônico se comparado ao estilo de pensamento da racionalidade ambiental. Aquela se expande desde a Revolução Industrial e impulsiona o pensamento único para disseminar a inexorabilidade advinda da produtividade capitalista, enquanto que a racionalidade ambiental ainda não reuniu todas as forças e o dinamismo necessários para destronar e se sobrepor à racionalidade econômica. Mesmo porque isto implicaria em demonstrar a perversidade sistêmica da econômica mundializada que o pensamento único se encarrega de divulgar e convencer.

Mas também é inegável que a racionalidade ambiental, neste contexto, encontra-se em desenvolvimento com todas as características da "protoideia ou pré-ideia", seguindo as análises de Fleck (2010, p. 64-69). Como protoideia, a racionalidade ambiental pode ser impulsionada ou pela mentalidade ideológica ou pela mentalidade utópica, seguindo as análises de Mannheim (1972). Para ele a mentalidade ideológica consiste num complexo de 


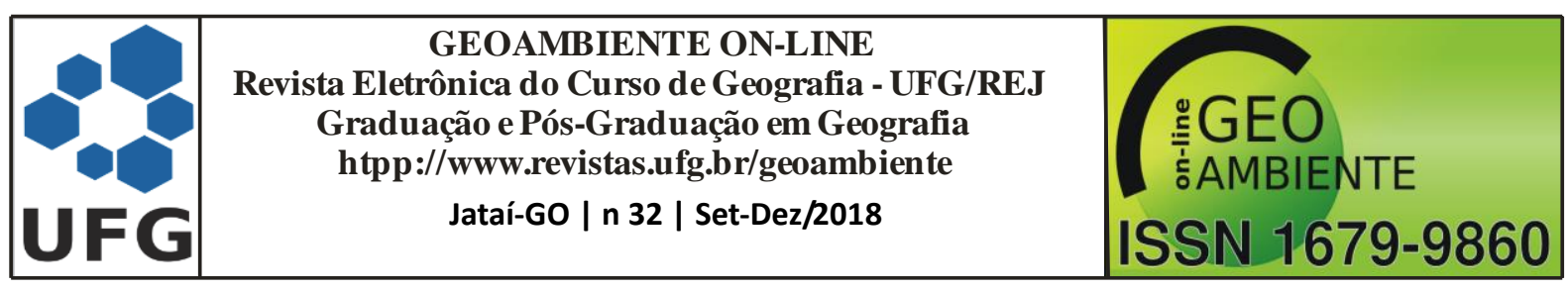

ideias orientadoras das atividades sociopolíticas tendo como objetivo a manutenção da ordem existente, enquanto a mentalidade utópica consiste num complexo de ideias geradoras das atividades sociopolíticas, tendo como objetivo implementar mudanças parciais ou totais na ordem existente.

Tanto a mentalidade ideológica quanto a utópica está em incongruência com o estado atual da ordem existente, pois o ser humano, como ser pensante, cria representações por intermédio das quais desenvolve um quadro de referências para captar objetos da realidade fenomênica. Tal realidade se constitui numa totalidade imediatamente acessível, mas caótica e obscura, razão pela qual Mannheim (1972, p. 216) esclarece que

[..] o homem tem-se ocupado mais frequentemente com objetos que transcendem seu âmbito de existência do que com os imanentes a ela e, apesar disso, formas efetivas e concretas de vida social têm sido construídas com base em tais estados de espírito "ideológicos" que estão em incongruência com a realidade.

O estado de espírito incongruente difere do congruente, em que este se adéqua e se amolda à ordem existente, enquanto aquele transcende e é irrealizável por não conseguir se efetivar plenamente na ordem existente. $\mathrm{O}$ estado de espírito incongruente, aquele que resiste a ordem existente por não se ajustar a ela, se efetiva de duas maneiras distintas, denominadas por Mannheim (1972, p. 218-219. Grifos no original) de "duas categorias principais de ideias que transcendem a situação - as ideologias e as utopias". Ele explica que

\footnotetext{
As ideologias são as ideias situacionalmente transcendentes que jamais conseguem de facto a realização de seus conteúdos pretendidos. Embora se tornem com frequência motivos bem intencionados para a conduta subjetiva do individuo, seus significados, quando incorporados efetivamente à pratica, são, na maior parte dos casos, deformados. [...] As utopias também transcendem a situação social, pois também orientam a conduta para elementos que a situação, tanto como se apresente em dada época, não contém. Mas não são ideologias, isto é, não são ideologias na medida e até o ponto em que conseguem, através de contra-atividade, transformar a realidade histórica existente em outra realidade, mais de acordo com suas próprias concepções.
}

A mentalidade ideológica é estranha à realidade e, mesmo que sua pretensão seja interferir e alterar provocando rupturas, é facilmente integrada na ordem existente, seja pelo amoldamento ou pela dissimulação. A mentalidade utópica também está em incongruência diante da ordem existente, porém, sua tendência consiste em transformar condutas para incidir parcial ou totalmente contra a ordem existente, abalando suas bases. 


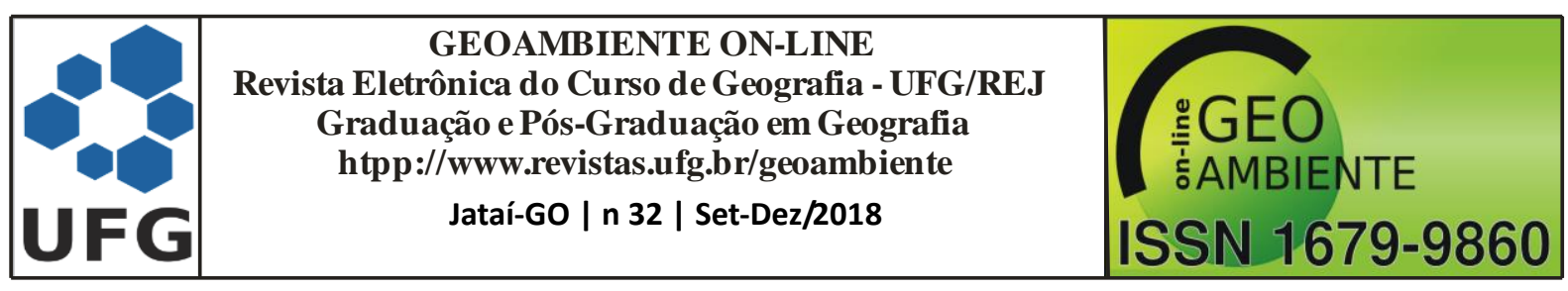

Como a realidade consiste num processo em constante transformação, é possível conceber a racionalidade ambiental utópica como a protoideia que se desenvolve construindo elementos intelectuais como material explosivo para romper os limites da ordem existente. A tendência dela consiste em transformar seus postulados em conduta histórica e política fornecendo subsídios que impulsionarão o desenvolvimento de um novo paradigma científico interdisciplinar para transformar a ordem vigente ou, ir transformando-a, para garantir o futuro das gerações em relação aos recursos naturais.

Neste sentido, a racionalidade ambiental ideológica consiste num discurso vazio e ardiloso a serviço do capital por defender a ordem vigente e esconder, camuflar os ataques do capital aos recursos naturais. Dissimula e justifica a necessidade inerente do capital de se desenvolver como enorme saqueador e depredador dos recursos naturais, mas efetivo e eficiente devido à sua inexorável produtividade em que pese o futuro das gerações em relação aos recursos naturais sempre escassos.

\section{Considerações Finais}

A racionalidade ambiental utópica não só é desejável como possível desde que se compreenda os laços coercíveis da racionalidade econômica juntamente com as possibilidades de se lançar um novo itinerário cujo trajeto provoque rupturas com a ordem existente. Tentar elucidar este itinerário foi o objetivo principal deste texto ao apontar os desdobramentos advindos das possibilidades do conhecimento em que o ser humano transita de ser cognoscitivo a ser cognitivo. Só o ser humano possui a capacidade da abstração e apenas ele é responsável pelo desenvolvimento de um sistema autopoiético.

Com a intensa troca de ideias dentro deste sistema, por intermédio da linguagem, proporciona o desenvolvimento da protoideia em ideia transpessoal na medida em que se expande um coletivo de pensamento com o seu estilo específico de pensar. A subordinação mental e a coerção obstaculizam o indivíduo pensar de maneira diferente, já que não é ele quem pensa, mas a comunidade que pensa nele. O vínculo do saber com o coletivo de pensamento produziu resultados interessantes quando, por exemplo, se analisa a transição da física clássica para física atômica.

Dentro do itinerário desta transição é esclarecedor que no emaranhado de opiniões, próprio de um coletivo de pensamento há espaços para emergir o estado de espírito 


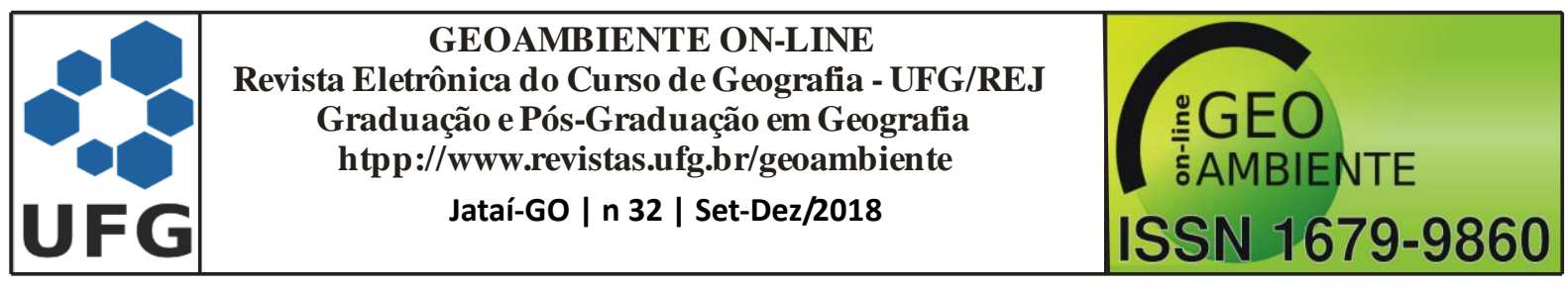

incongruente. $\mathrm{O}$ espírito incongruente é aquele que resiste a ordem existente por não se ajustar a ela e, pode se efetivar em duas direções: pela ideologia ou pela utopia. Ou seja, se ideológico será integrado e subordinado à ordem existente. Se utópico afrontará a ordem existente ao lançar rupturas nas suas bases de sustentação visando estabelecer transformações parciais ou totais, por acreditar possível construir outra ordem que substitua à existente. Desenvolver a racionalidade ambiental utópica contém estes e outros desafios.

\section{Referência Bibliográfica}

FLECK, Ludwik. Gênese e Desenvolvimento de um Fato Científico. Introdução à doutrina do estilo de pensamento e do coletivo de pensamento. Belo Horizonte: Fabrefactum Editora, 2010.

HEISENBERG, Werner. A Parte e o Todo: encontros e conversas sobre física, filosofia, religião e política. $5^{\mathrm{a}}$ reimp. Rio de Janeiro: Contraponto, 2011.

HUSSERL, Edmund. A Idéia da Fenomenologia Lisboa: Edições 70, 1986.

KOSIK, Karel. Dialética do Concreto. $3^{\text {a }}$ ed. Rio de Janeiro: Editora Paz e Terra, 1985

KUHN, Thomas S. A estrutura das revoluções científicas. $9^{a}$ ed. $1^{a}$ reimp. São Paulo: Editora Perspectiva, 2009.

LEFF, Enrique. Epistemologia Ambiental. 4a ed. São Paulo: Cortez, 2007.

MANNHEIM, Karl. Ideologia e Utopia. Rio de Janeiro: Zahar Editores, 1972. 